AGRITECH, Vol. 37, No. 3, Agustus 2017, Hal. 343-351 DOI: http://doi.org/10.22146/agritech.17177 ISSN 0216-0455 (Print), ISSN 2527-3825 (Online) Tersedia online di https://jurnal.ugm.ac.id/agritech/

\title{
Pengaruh Pelapisan Kitosan dan Suhu Penyimpanan terhadap Karakter Fisik Buah Sawo (Manilkara achras (Mill.) Fosberg) Selama Pematangan
}

\author{
Effects of Chitosan Coating and Storage Temperature on Physical Characteristic of Sapodillas \\ (Manilkara achras (Mill.) Fosberg) during Ripening \\ Widya Mudyantini ${ }^{1 *}$, S. Santosa ${ }^{2}$, Kumala Dewi ${ }^{3}$, Nursigit Bintoro ${ }^{4}$ \\ ${ }^{1}$ Program Studi Biologi, Fakultas Matematika dan Ilmu Pengetahuan Alam, \\ Universitas Sebelas Maret, Jl. Ir. Sutami 36 A Kentingan Surakarta 57126, Indonesia \\ ${ }^{2,3}$ Fakultas Biologi, Universitas Gadjah Mada Jl. Teknika Selatan Sekip Utara, Yogyakarta 55281, Indonesia \\ ${ }^{4}$ Departemen Teknik Pertanian dan Biosistem, Fakultas Teknologi Pertanian, Universitas Gadjah Mada, \\ Jl. Flora No. 1 Bulaksumur, Yogyakarta 55281, Indonesia \\ Email: widyamudyantini@yahoo.com
}

Submisi: 4 Maret 2016; Penerimaan: 20 Oktober 2016

\begin{abstract}
ABSTRAK
Buah sawo (Manilkara achras (Mill.) Fosberg) merupakan buah klimaterik yang mempunyai kulit tipis dan cepat matang. Tujuan penelitian ini adalah mengkaji pengaruh konsentrasi pelapisan kitosan dan suhu simpan terhadap sifat fisik dan kimiawi buah sawo serta menentukan konsentrasi pelapisan kitosan dan suhu simpan yang paling optimum untuk memperpanjang masa simpan buah sawo. Rancangan penelitian yang digunakan adalah Split Plot Design pola faktorial dengan dua faktor, yaitu suhu penyimpanan terdiri dari tiga taraf $\left(5^{\circ} \mathrm{C}, 15^{\circ} \mathrm{C}, 25^{\circ} \mathrm{C}\right)$ sebagai faktor utama dan konsentrasi kitosan yang terdiri dari empat taraf $(0 \%, 2 \%, 3 \%, 4 \%)$ sebagai sub faktor. Setiap kombinasi dengan lima ulangan. Data dianalisis menggunakan Analisis Varian (ANAVA) kemudian dilanjutkan dengan uji Duncan's Multiple Range Test (DMRT) pada taraf uji 5\%. Buah dengan umur fisiologis sama, berat $100-120 \mathrm{~g}$ dipanen dari satu pohon. Buah diberi perlakuan pelapisan kitosan dan disimpan pada temperatur yang berbeda, selanjutnya diamati sampai buah tidak layak dikonsumsi. Parameter yang diamati adalah tebal lapisan kitosan berbagai konsentrasi pada kulit buah, permeabilitas membran kitosan terhadap uap air dan $\mathrm{O}_{2}$, masa simpan, kekerasan buah, kandungan klorofil dan karotenoid serta laju respirasi. Hasil yang diperoleh menunjukkan semakin tinggi konsentrasi kitosan, semakin terhambat masuknya uap air dan oksigen ke dalam kulit buah, tetapi konsentrasi kitosan $4 \%$ dan suhu $5{ }^{\circ} \mathrm{C}$ menyebabkan lapisan kitosan mengelupas. Perlakuan konsentrasi pelapisan kitosan $(0 \%, 2 \%, 3 \%, 4 \%)$ dan suhu simpan $\left(5^{\circ} \mathrm{C}, 15^{\circ} \mathrm{C}\right.$, $25^{\circ} \mathrm{C}$ ) serta interaksinya mengakibatkan semakin tinggi konsentrasi kitosan, kekerasan buah sawo semakin meningkat, juga kadar klorofil kulit buah. Semakin buah matang kadar karotenoid semakin meningkat, demikian juga $\operatorname{kadar} \mathrm{CO}_{2}$. Kadar oksigen semakin menurun seiring dengan pemasakan buah. Perlakuan optimum untuk mempertahankan masa simpan buah sawo adalah perlakuan pelapisan kitosan $3 \%$ dan suhu simpan $5{ }^{\circ} \mathrm{C}$.
\end{abstract}

Kata kunci: Kitosan; karakter fisik; sawo (Manilkara achras (Mill.) Fosberg); suhu

\begin{abstract}
Sapodilla (Manilkara achras (Mill.) Fosberg) is a climacteric and highly perishable fruit with thin peel. The objectives of this study were: (1) to examine the effect of chitosan coating concentrations and storage temperature on the physical and chemical characteristics of sapodilla and (2) to determine the chitosan coating concentrations and the optimum storage temperature for the storage of sapodilla. Factorial Split-Plot Design was used in this experiment: three levels
\end{abstract}


of storage temperature as the main factors $\left(5^{\circ} \mathrm{C}, 15^{\circ} \mathrm{C}, 25^{\circ} \mathrm{C}\right)$ and four levels of chitosan concentrations $(0 \%, 2 \%$, $3 \%, 4 \%)$ as the sub-factors. Each treatment was made in five replicates. Collected data were analyzed using analysis of variance (ANOVA) followed by the Duncan's Multiple Test (DMRT) at the test level of 5\%. Sapodillas used in this study had the same age in the weight of 100-120 grams and were harvested from the same tree. They were observed until rotten. The parameters observed were the concentrations of chitosan coating thickness on sapodillas'peel, the permeability of chitosan membrane to the air water vapour and oxygen shelf life, hardness, content of chlorophyll and carotenoid, and respiration of the fruit. Observed data showed that the higher chitosan concentrations was used, the higher capability of the sapodilla's peel to hampered water vapour and oxygen's to peddix the peel. However, the chitosan coating concentration of $4 \%$ and the storage temperature of $5{ }^{\circ} \mathrm{C}$ temperature made the chitosan layer flaked. The treated concentrations of chitosan coating $(0 \%, 2 \%, 3 \%, 4 \%)$ at certain storage temperature variations $\left(5^{\circ} \mathrm{C}, 15^{\circ} \mathrm{C}\right.$, $25^{\circ} \mathrm{C}$ ) and their interactions had an effect on the physical characters of sapodilla in all parameters. The higher coated chitosan concentration applied, the hardness of sapodilla increased. The chlorophyll contents of sapodilla peel were increasing along with the hampering of the ripening. When the sapodillas were ripe, the carotenoid contents increated. The oxygen contents were decreasing along with the ripening of the sapodillas. The $\mathrm{CO}_{2}$ contents were increasing along with the ripening process of the sapodillas. The optimum treatment to keep sapodillas' shelf life was the chitosan coating of $3 \%$ and the the storage temperature of $5{ }^{\circ} \mathrm{C}$.

Keywords: Chitosan; physical characters; sapodilla (Manilkara achras (Mill.) Fosberg); temperature

\section{PENDAHULUAN}

Sawo (Manilkara achras (Mill.) Fosberg) termasuk buah berdaging dengan kulit tipis (Pantastico, 1993). Permintaan pasar buah sawo cukup tinggi karena rasanya yang manis dan khas. Umur simpan buah sawo yang telah matang tidak lebih dari satu minggu (3-5 hari) pada suhu kamar (Kurniawan dkk., 2013). Karakter buah sawo yang berkulit tipis, berdaging dengan kandungan karbohidrat dan air tinggi, serta masa simpan yang pendek menarik dan perlu untuk diteliti.

Pelapisan pada buah dapat memberikan kekuatan mekanik pada kulit dan menahan pertukaran gas yang masuk atau keluar melalui kulit buah serta mengurangi respirasi buah (Chailoo dan Asghari, 2011). Bahan yang dipakai untuk pelapis buah harus aman dikonsumsi manusia. Salah satu bahan yang aman dan sudah banyak dipakai antara lain adalah kitosan (Donhowe dan Fennema, 1994). Keunggulan kitosan selain aman dikonsumsi (karena berasal dari cangkang hewan laut) juga mampu membentuk lapisan film yang kuat, elastis, fleksibel, sulit dirobek (Abdou dkk., 2008) dan menghambat pertumbuhan mikroba (Wahab dan Rashid, 2012; Shehata dkk., 2012). Edible coating adalah suatu metode pemberian lapisan tipis pada permukaan buah untuk menghambat keluarnya gas, uap air, dan menghindari kontak dengan oksigen, sehingga proses pemasakan dan pencoklatan buah dapat diperlambat (Ghaouth dkk., 1992). Edible coating berfungsi sebagai penghalang terhadap kelembaban, oksigen dan cahaya (Bourtoom, 2008). Salah satu bahan edible coating adalah kitosan. Bahan ini dipilih karena memiliki karakteristik tidak berbau, tidak berasa, fleksibel, dan transparan. Lapisan yang ditambahkan di permukaan buah ini tidak berbahaya bila ikut dikonsumsi bersama buah. Pelapisan ini juga memperkuat kulit buah yang tipis. Kitosan adalah salah satu bahan yang bisa digunakan sebagai pelapis buah yang merupakan golongan polisakarida.

Penyimpanan buah pada temperatur rendah adalah perlakuan yang efektif menurunkan laju respirasi (Paramita, 2010), hal ini disebabkan karena aktivitas metabolisme dan enzim akan menurun pada suhu rendah (Paramita, 2010). Suhu rendah juga akan menghambat produksi etilen. Setiap kenaikan suhu $10{ }^{\circ} \mathrm{C}$ laju respirasi pada sel juga akan meningkat dua atau tiga kali (Dopico dkk., 1993). Kombinasi perlakuan suhu rendah dan kitosan ini diharapkan dapat lebih meningkatkan masa simpan dan kekuatan mekanik pada kulit, daripada hanya salah satu perlakuan saja. Adapun tujuan penelitian ini adalah mengkaji pengaruh konsentrasi pelapisan kitosan dan suhu simpan terhadap sifat fisik dan kimiawi buah sawo serta menentukan konsentrasi pelapisan kitosan dan suhu simpan yang paling optimum untuk memperpanjang masa simpan buah sawo.

\section{METODE PENELITIAN}

\section{Bahan}

Bahan yang digunakan dalam penelitian ini adalah buah sawo yang dipanen dari satu pohon di daerah Purwanggan Solo. Buah sawo dipanen dan diseleksi dengan kriteria tingkat kematangan yang sama (keseragaman warna kulit buah diukur dengan Munsell Color Charts for Plant Tissues) yaitu $5 Y(7 / 10$ to $7 / 12)$ dan tingkat kekerasan buah diukur dengan penetrometer Electric BI-235. Sebagai pedoman, buah yang akan dipakai dalam perlakuan: berat buah berkisar antara 
100-120 g, dan tidak berpenyakit. Buah dicuci dengan air mengalir kemudian disterilkan dengan clorox $2 \%$ pada bak besar dan selanjutnya dikeringanginkan di dalam ruangan. Adapun kemikalia yang digunakan adalah kitosan yang diperoleh dari Lab. Teknologi Hasil Perairan IPB (derajat deasetilasi $82 \%$ ), aseton $80 \%$, etil asetat, metanol, $\mathrm{NaHCO}_{2}$, acetonitril, $\mathrm{CH}_{3} \mathrm{COOH}$, aquabides, dan aquades.

\section{Alat}

Alat yang digunakan dalam penelitian ini meliputi, Munsell Color Charts for Plant Tissues (New York), timbangan analitik merk Mettler Toledo tipe MS 303 New Classic (Switzerland), refrigerator laboratory merk Thermo Scientific (Amerika), mikroskop merk Nikon tipe Eclips 600 dengan software NIS Elements (Jepang), penetrometer merk Takemura tipe 510-1 (FHM-1) Electric BI-235 (Jepang), spektrofotometer tipe Lamda 25 merk Perkin Elmer (Amerika), oksigen meter merk Lutron tipe DO 5510, $\mathrm{CO}_{2}$ meter merk Lutron 2028, humidity meter Model GCH 2018 (Taiwan).

\section{Rancangan Penelitian}

Rancangan penelitian yang digunakan adalah Split Plot Design pola faktorial dengan dua faktor, yaitu suhu penyimpanan terdiri dari tiga taraf $\left(5{ }^{\circ} \mathrm{C}, 15{ }^{\circ} \mathrm{C}, 25^{\circ} \mathrm{C}\right)$ sebagai faktor utama dan konsentrasi kitosan yang terdiri dari empat taraf $(0 \%, 2 \%, 3 \%$ dan $4 \%)$ sebagai sub faktor sehingga diperoleh 12 kombinasi perlakuan. Setiap kombinasi perlakuan dengan lima ulangan. Data dianalisis menggunakan Analisis Varian (ANAVA) kemudian dilanjutkan dengan uji Duncan's Multiple Range Test (DMRT) pada taraf uji 5\% untuk mengetahui beda nyata antar perlakuan.

\section{Cara Kerja}

Pelapis kitosan dibuat dengan konsentrasi $0 \%, 2 \%, 3 \%$, dan $4 \%$. Kitosan dilarutkan dalam asam asetat $1 \%$ dan disaring. Larutan yang tersaring diaduk dengan magnetic stirer selama 15 menit. Buah sawo dicelupkan ke dalam larutan kitosan dengan berbagai variasi konsentrasi tersebut selama 10 menit, kemudian ditiriskan pada bak plastik sampai kering. Buah sawo yang telah dilapisi kitosan kemudian disimpan pada suhu $5{ }^{\circ} \mathrm{C}, 15^{\circ} \mathrm{C}$, dan $25^{\circ} \mathrm{C}$. Kontrol adalah perlakuan konsentrasi kitosan $0 \%$ pada suhu $25^{\circ} \mathrm{C}$. Pengamatan kadar $\mathrm{O}_{2}$ dan $\mathrm{CO}_{2}$ dalam toples serta warna dilakukan setiap hari sampai buah tidak layak konsumsi (hari ke-7). Pengukuran ketebalan lapisan, permeabilitas membran kitosan terhadap $\mathrm{O}_{2}$ dan uap air dilakukan terhadap lembaran membran kitosan tanpa perlakuan suhu. Adapun pengukuran kekerasan, kadar klorofil, karotenoid dilakukan hanya sekali pada hari terakhir saat kontrol $\left(0 \%\right.$ dan suhu $\left.25{ }^{\circ} \mathrm{C}\right)$ tidak layak konsumsi (hari
$15{ }^{\circ} \mathrm{C}$ ) dilanjutkan sampai buah tidak layak konsumsi.

Pembuatan membran kitosan pada konsentrasi $2 \%$, $3 \%$, dan $4 \%$ dilakukan dengan mencelupkan cetakan pada ketiga larutan kitosan tersebut. Setelah ditiriskan sampai tidak menetes, cetakan dikeringanginkan sampai membran kitosan terkelupas dari cetakan. Membran kitosan ini diukur permeabilitasnya terhadap $\mathrm{O}_{2}$ dan uap air.

Irisan penampang melintang kulit sawo yang telah dilapisi kitosan pada berbagai variasi konsentrasi perlakuan (0 \%, 2\%, 3\%, dan 4\%) dibuat dengan metode Free Hand Section. Ketebalan lapisan kitosan pada kulit diukur, diamati dan didokumentasi dengan mikroskop kamera perbesaran 400X. Uji tekstur (kekerasan) buah dilakukan dengan meletakkan buah tepat di bawah jarum penusuk penetrometer.

Kandungan klorofil dan karotenoid diukur dengan cara, $1 \mathrm{~g}$ kulit dan daging buah dihaluskan kemudian ditambah $10 \mathrm{ml}$ etanol $80 \%$ diukur serapannya pada beberapa panjang gelombang dengan Spektrofotometer UV Vis (Richardson dkk., 2002). Adapun total klorofil dan karotenoid dihitung dengan menurut persamaan Jaleel dan Azooz (2009).

Uji permeabilitas membran kitosan terhadap oksigen menggunakan metode ASTM (2004) dimodifikasi dengan Zeman dan Kubik (2012). Toples kecil yang di permukaan mulut atasnya diletakkan membran kitosan, dipasangi probe oksigen meter, kemudian toples kecil tersebut dimasukkan ke toples besar yang sudah ada probe oksigen meternya. Volume toples kecil adalah $282,6 \mathrm{~cm}^{3}$ volume toples besar 4310,44 $\mathrm{cm}^{3}$. Oksigen disemprotkan ke toples besar. Dicatat perubahan konsentrasi oksigen secara periodik tiap 1 jam sampai terjadi keseimbangan antara kedua toples. Permeabilitas membran dihitung sesuai Persamaan 1 (Zeman dan Kubik, 2012):

$$
\begin{aligned}
& \mathrm{Px}=\Delta \mathrm{pp} V M \\
& \Delta t \mathrm{~S}_{\mathrm{p}_{\mathrm{i}}^{2} \mathrm{RT}}
\end{aligned}
$$

Uji permeabilitas membran terhadap uap air dilakukan dengan metode ASTM (2004) dimodifikasi dengan Donhowe dan Fennema (1993). Toples besar berisi air 1/3 bagian yang sudah terpasangi probe RH meter. Ditimbang $3 \mathrm{~g}$ silika gel dan diletakkan pada cawan. Disiapkan toples kecil yang telah diberi probe RH meter. Silika gel dimasukkan ke dalam toples kecil dengan membran kitosan yang diletakkan pada mulut toples. Toples kecil ini diletakkan dalam toples besar. Diukur kelembaban awal pada masing-masing toples. Dihitung selisih berat silika gel akhir dengan awalnya setelah 24 jam. Dihitung laju permeasi uap air dengan Persamaan 2 (Donhowe dan Fennema, 1993).

Laju permeasi uap air : $\quad \frac{\Delta \mathrm{W}}{\Delta \mathrm{x} t}$ 
Adapun untuk pengamatan respirasi diukur dengan metode persamaan statis. Buah sawo 0,5 kg yang sudah dilapisi kitosan dimasukkan ke dalam toples. Konsentrasi oksigen diukur dengan oksigen meter Lutron 5510, adapun karbondioksida yang dihasilkan diukur dengan alat CO2 meter Lutron 2028. Pengamatan dilakukan setiap hari sampai kontrol (perlakuan konsentrasi kitosan $0 \%$ dengan suhu penyimpanan $25^{\circ} \mathrm{C}$ ) tidak layak konsumsi.

\section{HASIL DAN PEMBAHASAN}

\section{Ketebalan Lapisan Kitosan pada Kulit Buah Sawo}

Hasil analisis statistik menunjukkan bahwa perbedaan konsentrasi kitosan berbeda nyata terhadap ketebalan dan kedalaman penetrasi kitosan ke dalam kulit buah sawo. Semakin tinggi konsentrasi kitosan, semakin tebal membran yang melapisi kulit buah sawo. Pada konsentrasi kitosan 4\% larutan yang diperoleh sangat pekat, sehingga rendah kemampuannya menembus ruang antar sel atau lentisel epidermis kulit, bahkan pada penyimpanan suhu $5^{\circ} \mathrm{C}$ lapisan kitosan tersebut mudah mengelupas. Data ketebalan lapisan kitosan yang terbentuk dari berbagai konsentrasi kitosan yang diaplikasikan pada kulit buah sawo ditunjukkan pada Tabel 1.

Kulit buah sawo sangat tipis, epidermis hanya tersusun atas 1-3 lapis sel dan terdapat lentisel yang berisi sel gabus. Lapisan kitosan akan menempel pada epidermis kulit. Semakin rendah konsentrasi kitosan, semakin mudah larutan menembus ruang antar sel dan lentisel, sehingga lapisan yang terbentuk pada permukaan kulit buah semakin tipis. Hal ini ditunjukkan oleh ketebalan lapisan kitosan pada permukaan kulit sawo yang semakin tipis dengan semakin rendahnya konsentrasi kitosan. Pada konsentrasi kitosan 4\% terbentuk lapisan tebal di permukaan kulit buah $(19,2 \mu \mathrm{m})$, tetapi penetrasi larutan kitosan ke dalam sel rendah sekali $(1,5 \mu \mathrm{m})$ sehingga lapisan kitosan mudah mengelupas. Semua ulangan perlakuan konsentrasi $4 \%$ dan suhu $5^{\circ} \mathrm{C}$ kulitnya mengelupas.

Tabel 1. Ketebalan dan penetrasi lapisan kitosan di kulit buah sawo (Manilkara achras (Mill.) Fosberg) $(\mu \mathrm{m})$

\begin{tabular}{ccc}
\hline $\begin{array}{c}\text { Konsentrasi } \\
\text { kitosan }(\%)\end{array}$ & $\begin{array}{c}\text { Ketebalan } \\
\text { lapisan } \\
\text { kitosan }(\mu \mathrm{m})\end{array}$ & $\begin{array}{c}\text { Penetrasi ke dalam } \\
\text { sel epidermis kulit } \\
\text { buah }(\mu \mathrm{m})\end{array}$ \\
\hline 2 & $4,2^{\mathrm{a}}$ & $4,2^{\mathrm{m}}$ \\
3 & $8,0^{\mathrm{b}}$ & $3,5^{1}$ \\
4 & $19,2^{\mathrm{c}}$ & $1,5^{\mathrm{k}}$ \\
\hline
\end{tabular}

Angka yang disertai dengan huruf yang sama pada baris/kolom menunjukkan tidak beda nyata pada taraf uji $5 \%(n=5)$.

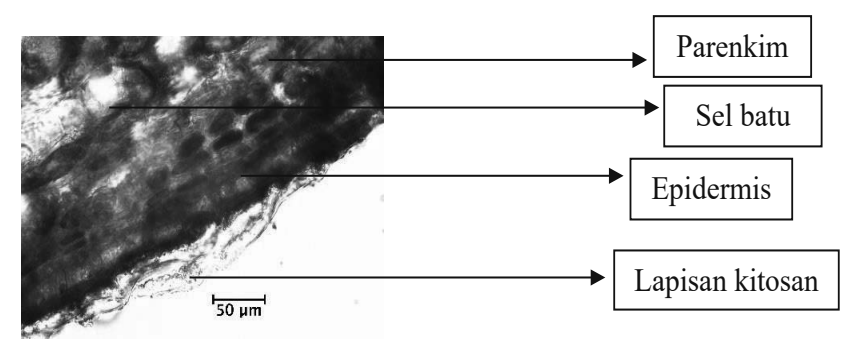

Gambar 1. Penampang lintang kulit buah sawo dengan pelapisan kitosan (perbesaran 400X)

Pada perlakuan suhu rendah kadar air dalam lapisan kitosan semakin kecil sehingga lapisan mudah rusak. Adapun gambar penampang lintang kulit buah sawo setelah dilapisi kitosan disajikan pada Gambar 1 .

\section{Permeabilitas Membran Kitosan terhadap Oksigen}

Hasil pengukuran yang dilakukan pada berbagai konsentrasi membran kitosan tanpa perlakuan suhu, menunjukkan bahwa semakin tinggi konsentrasi kitosan maka kemampuan lapisan menghambat oksigen yang masuk ke dalam kulit semakin tinggi. Oksigen merupakan gas yang sangat mudah keluar dan masuk dalam pori yang sangat kecil. Semakin pekat larutan (4\%) dan semakin tebal lapisan yang terbentuk, maka porinya pada lapisan kitosan yang terbentuk juga semakin kecil sehingga oksigen makin sulit masuk (paling rendah yaitu 0,016). Menurut Rohman dkk. (2009), kitosan 3\% membentuk lapisan yang memiliki diameter pori $0,256 \mu \mathrm{m}$, sedangkan lapisan kitosan yang terbentuk dari larutan kitosan $4 \%$ yaitu $0,112 \mu \mathrm{m}$. Permeabilitas lapisan kitosan terhadap $\mathrm{O}_{2}$ ditunjukkan pada Tabel 2.

Tabel 2. Permeabilitas lapisan kitosan yang terbentuk dari berbagai konsentrasi terhadap $\mathrm{O}_{2}\left(\mathrm{~cm}^{-3} \mathrm{~cm}^{-2} \mathrm{~s}^{-1} \mathrm{~Pa}^{-1}\right)$.

\begin{tabular}{cc}
\hline Konsentrasi kitosan $(\%)$ & $\begin{array}{c}\text { Permeabilitas membran } \\
\text { kitosan terhadap } \mathrm{O}_{2} \\
\left(\mathrm{~cm}^{-3} \mathrm{~cm}^{-2} \mathrm{~s}^{-1} \mathrm{~Pa}^{-1}\right)\end{array}$ \\
\hline 2 & $0,060^{\mathrm{a}}$ \\
3 & $0,036^{\mathrm{b}}$ \\
4 & $0,016^{\mathrm{c}}$ \\
\hline
\end{tabular}

Angka yang disertai dengan huruf yang sama pada baris/kolom menunjukkan tidak beda nyata pada taraf uji $5 \%$.

\section{Permeabilitas Membran Kitosan terhadap Uap air}

Permeabilitas lapisan kitosan yang terbentuk dari berbagai konsentrasi terhadap uap air ditunjukkan pada Tabel 3. Permeabilitas lapisan kitosan terhadap uap air juga dipengaruhi oleh ketebalan lapisan. Lapisan kitosan yang semakin tebal, kemampuannya menghambat uap air juga semakin tinggi. 
Tabel 3. Permeabilitas lapisan kitosan terbentuk dari berbagai berbagai konsentrasi terhadap uap air (mg/ $\left.\mathrm{cm}^{2} / \mathrm{jam}\right)$.

\begin{tabular}{cc}
\hline $\begin{array}{c}\text { Konsentrasi } \\
\text { kitosan }(\%)\end{array}$ & $\begin{array}{c}\text { Permeabilitas lapisan terhadap } \\
\text { uap air }\left(\mathrm{mg} / \mathrm{cm}^{2} / \mathrm{jam}\right)\end{array}$ \\
\hline 2 & $1,051^{\mathrm{c}}$ \\
3 & $1,019^{\mathrm{b}}$ \\
4 & $1,009^{\mathrm{a}}$ \\
\hline
\end{tabular}

Angka yang disertai dengan huruf yang sama pada baris/kolom menunjukkan tidak beda nyata pada taraf uji $5 \%(n=5)$.

Data hasil penelitian menunjukkan bahwa peningkatan konsentrasi kitosan secara nyata meningkatkan permeabilitas membran kitosan terhadap uap air. Semakin tinggi konsentrasi larutan kitosannya semakin tinggi pula nilai permeabilitas membrannya terhadap uap air. Hal ini disebabkan semakin tinggi konsentrasi kitosan maka viskositas larutan semakin tinggi sehingga tahanan yang ditimbulkan oleh membran juga semakin tinggi dan laju volumetrik air menjadi semakin kecil.

\section{Masa Simpan Buah Sawo setelah Perlakuan Kitosan dan Suhu Rendah}

Data masa simpan buah sawo setelah perlakuan dengan pelapisan kitosan dan penyimpanan suhu rendah dapat dilihat pada Tabel 4. Masa simpan terlama adalah 21 hari pada perlakuan suhu $5{ }^{\circ} \mathrm{C}$, kemudian 16 hari pada suhu $15^{\circ} \mathrm{C}$ dan suhu $25^{\circ} \mathrm{C}$ selama 7 hari. Semakin dingin suhu, masa simpan semakin lama.

Tabel potongan membujur buah sawo setelah pelapisan dengan berbagai konsentrasi kitosan dan penyimpanan pada suhu 5, 15, dan $25^{\circ} \mathrm{C}$ ditunjukkan pada Tabel 5 dan 6. Pada Tabel 6 pengamatan diteruskan hanya untuk perlakuan suhu rendah $5{ }^{\circ} \mathrm{C}$ dan $15^{\circ} \mathrm{C}$ saja, karena kontrol sudah tidak layak konsumsi pada hari ke-7.

Hasil pengamatan menunjukkan bahwa perlakuan terbaik adalah pada pelapisan kitosan $3 \%$ dan suhu $5{ }^{\circ} \mathrm{C}$, karena pada perlakuan ini buah tetap keras, daging buah

Tabel 4. Lama masa simpan buah sawo setelah pelapisan dengan kitosan dan penyimpanan suhu rendah (hari)

\begin{tabular}{cc}
\hline $\begin{array}{c}\text { Suhu } \\
\left({ }^{\circ} \mathrm{C}\right)\end{array}$ & $\begin{array}{c}\text { Lama masa simpan sampai kontrol } \\
\text { tidak layak konsumsi (hari) }\end{array}$ \\
\hline 5 & $21^{\mathrm{c}}$ \\
15 & $16^{\mathrm{b}}$ \\
25 & $7^{\mathrm{a}}$ \\
\hline
\end{tabular}

$\overline{\text { Angka yang disertai dengan huruf yang sama pada baris/kolom menunjukkan }}$ tidak beda nyata pada taraf uji $5 \%(\mathrm{n}=5)$.
Tabel 5. Tekstur potongan buah sawo setelah perlakuan dengan berbagai konsentrasi pelapisan kitosan pada suhu simpan $5{ }^{\circ} \mathrm{C}, 15^{\circ} \mathrm{C}$, dan $25^{\circ} \mathrm{C}$ selama 7 hari.

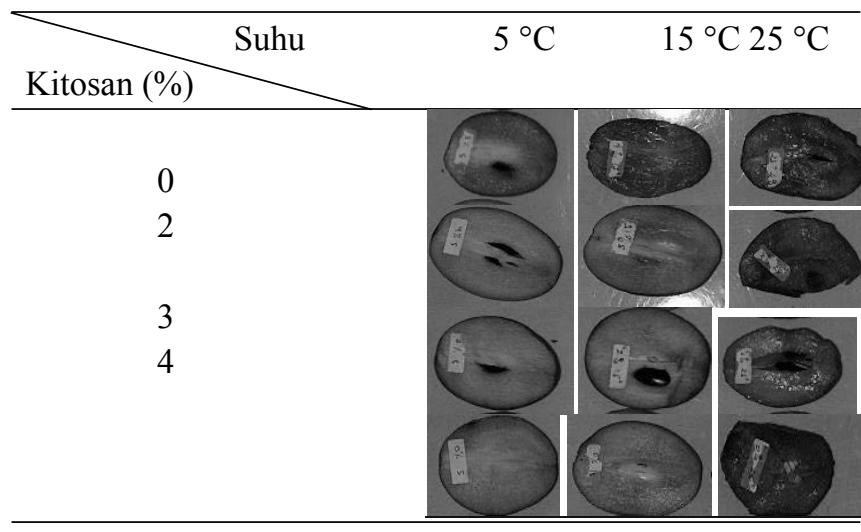

Tabel 6. Buah sawo setelah perlakuan dengan berbagai konsentrasi pelapisan kitosan dan suhu simpan $5{ }^{\circ} \mathrm{C}$ serta $15^{\circ} \mathrm{C}$ selama 21 hari

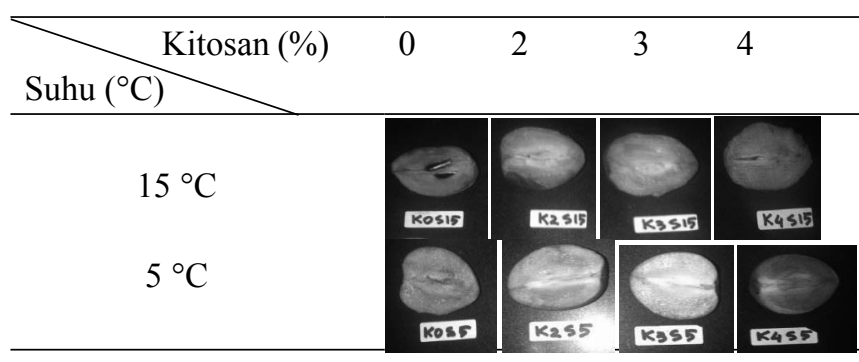

kuning keputihan, tidak berair, warna kulit kuning kehijauan sedang pada buah lain sudah kecoklatan. Buah sawo yang dianggap tidak layak konsumsi adalah buah yang sudah busuk dengan tanda sebagai berikut: rasa masam, kulit buah keriput, kadar air tinggi, nilai kekerasan 0, aromanya tidak harum, warna pada Munsell Color Charts 7,5 YR (6/10 to 6/12).

\section{Laju Respirasi}

Data hasil respirasi buah sawo setelah perlakuan pelapisan kitosan dan suhu ditunjukkan pada Gambar 2 dan 3. Berdasarkan grafik kadar $\mathrm{O}_{2}$ di dalam toples terlihat bahwa kelompok kurva perlakuan suhu $5{ }^{\circ} \mathrm{C}$ ada di bagian atas, sedangkan suhu $25^{\circ} \mathrm{C}$ ada di bagian bawah, sedangkan perlakuan $15{ }^{\circ} \mathrm{C}$ ada sebagian di bawah dan sebagian di atas. Terlihat bahwa semakin tinggi suhu, semakin tinggi juga respirasi ditunjukkan dengan oksigen yang digunakan sebagai substrat respirasi semakin banyak. Semakin tinggi kadar $\mathrm{O}_{2}$ di dalam toples maka semakin kecil $\mathrm{O}_{2}$ yang digunakan buah sawo untuk respirasi, sebaliknya semakin rendah kadar $\mathrm{O}_{2}$ dalam toples, semakin banyak $\mathrm{O}_{2}$ yang digunakan untuk respirasi buah. Suhu $25{ }^{\circ} \mathrm{C}$ paling tinggi respirasinya. Kadar oksigen tertinggi diperoleh pada penyimpanan suhu $5{ }^{\circ} \mathrm{C}$ 


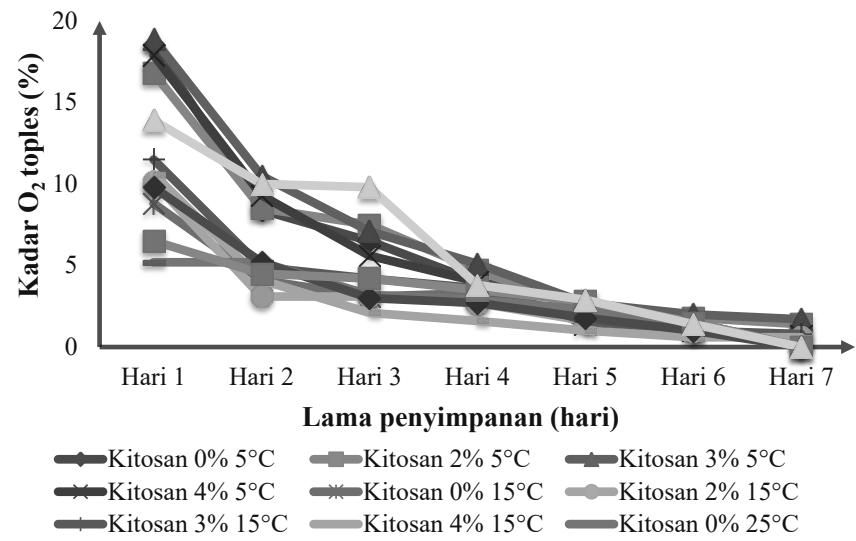

Gambar 2. Kadar $\mathrm{O}_{2}$ dalam toplesbuah sawo selama pematangan setelah perlakuan pelapisan kitosan dan suhu rendah (\%)

dan pelapisan 3\% yang menunjukkan tingkat respirasi yang paling rendah.

Selama proses pematangan, kegiatan dalam sel-sel buah menjadi meningkat sehingga diperlukan energi yang diperoleh dari ATP (Heldt, 2005). Meningkatnya kegiatan mitokondria memproduksi ATP tersebut menyebabkan proses respirasi juga mengalami peningkatan sehingga terjadinya proses klimaterik pada buah tertentu (Dirk, 2007). Pelapisan kitosan pada berbagai konsentrasi menyebabkan tertutupnya pori-pori permukaan kulit buah sehingga aktivitas respirasi dan transpirasi pada buah dapat terhambat atau berkurang.

Pada suhu dingin dapat terjadi perubahan yang sangat menyolok pada kecepatan glikolisis dan respirasi mitokondria, yang mengakibatkan laju respirasi menjadi lambat dibandingkan dengan suhu tinggi. Penelitian Paramita (2010), menyatakan bahwa mangga gedong gincu yang disimpan dalam suhu $10{ }^{\circ} \mathrm{C}$ mempunyai laju respirasi paling rendah dibandingkan dengan mangga gedong gincu yang disimpan pada suhu $20^{\circ} \mathrm{C}$ dan $25^{\circ} \mathrm{C}$. Beckett (1995), menyatakan bahwa suhu rendah akan mereduksi laju respirasi dan transpirasi, menghambat reaksi enzimatis, menekan laju pertumbuhan mikroorganisme dan memperlambat laju produksi etilen, serta laju kemunduran mutu produk. Adapun data kadar $\mathrm{CO}_{2}$ selama respirasi buah sawo setelah pelapisan dengan kitosan dan penyimpanan pada berbagai variasi suhu ditunjukkan Gambar 3.

Kadar $\mathrm{CO}_{2}$ di dalam toples menunjukkan fenomena yang berbalik dengan $\mathrm{O}_{2}$. Semakin tinggi kadar $\mathrm{CO}_{2}$ berarti respirasi semakin meningkat seperti terlihat pada suhu $25^{\circ} \mathrm{C}$. Respirasi pada suhu $5{ }^{\circ} \mathrm{C}$ lebih rendah. Semakin hari kadar $\mathrm{CO}_{2}$ semakin meningkat. Pelapisan kitosan pada berbagai konsentrasi menyebabkan tertutupnya permukaan kulit buah sehingga aktivitas respirasi dan transpirasi pada buah dapat terhambat atau berkurang (Santosa, 2011).

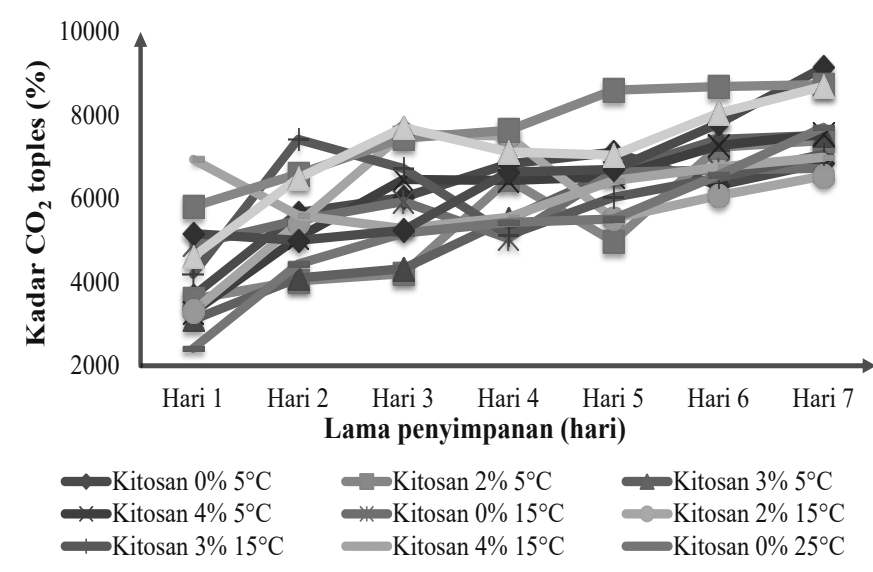

Gambar 3. Kadar $\mathrm{CO}_{2}$ toples buah sawo selama pematangan setelah perlakuan pelapisan kitosan dan suhu (\%)

\section{Kekerasan Kulit Buah Sawo setelah Perlakuan Kitosan dan Suhu Rendah}

Hasil penelitian menunjukkan bahwa interaksi suhu simpan dengan konsentrasi kitosan mempengaruhi kekerasan buah sawo. Semakin rendah suhu, kekerasan buah semakin meningkat. Semakin tebal lapisan, kekerasan buah sawo juga semakin meningkat. Perlakuan konsentrasi kitosan 3\% dan suhu penyimpanan $5{ }^{\circ} \mathrm{C}$ efektif mempertahankan kekerasan buah sawo. Pada perlakuan konsentrasi kitosan 4\% dan suhu penyimpanan $5{ }^{\circ} \mathrm{C}$, buah menjadi keras sekali dan lapisan kitosannya mengelupas. Data kekerasan buah sawo setelah dilapisi kitosan dan diberi perlakuan suhu rendah ditunjukkan Tabel 7.

Pada awal penyimpanan terjadi penurunan kekerasan kulit buah. Hal ini dapat disebabkan oleh pecahnya propektin menjadi zat dengan berat molekul yang lebih rendah karena aktivitas enzim poligalakturonase. Enzim poligalakturonase menguraikan propektin dengan komponen utama asam poligalakturonat menjadi asam galakturonat sehingga larut dalam air dan mengakibatkan lemahnya dinding sel dan turunnya daya kohesi yang mengikat satu dengan yang

Tabel 7. Kekerasan buah sawo (Manilkara achras (Mill.) Fosberg) setelah perlakuan dengan pelapisan kitosan dan penyimpanan suhu rendah selama tujuh hari $(\mathrm{kg})$

\begin{tabular}{cccc}
\hline Kitosan (\%) & $5{ }^{\circ} \mathrm{C}$ & $15^{\circ} \mathrm{C}$ & $25^{\circ} \mathrm{C}$ \\
\hline 0 & $0,39^{\mathrm{g}}$ & $0,06^{\mathrm{b}}$ & $0,20^{\mathrm{a}}$ \\
2 & $0,43^{\mathrm{h}}$ & $0,14^{\mathrm{d}}$ & $0,06^{\mathrm{b}}$ \\
3 & $0,51^{\mathrm{i}}$ & $0,20^{\mathrm{e}}$ & $0,09^{\mathrm{c}}$ \\
4 & $0,56^{\mathrm{j}}$ & $0,35^{\mathrm{f}}$ & $0,15^{\mathrm{d}}$ \\
\hline
\end{tabular}

Angka yang disertai dengan huruf yang sama pada baris/kolom menunjukkan tidak beda nyata pada taraf uji $5 \%(n=5)$. 
lainnya (Pantastico, 1993). Menurut Winarno (2002), tekstur buah menjadi lunak selama penyimpanan disebabkan pecahnya pektin dan hemiselulosa, sehingga kekerasan buah menurun. Selama penyimpanan buah terjadi pemecahan pektin, disebabkan oleh aktivitas enzim pektin metil esterase dan poligalakturonase, sebagian propektin tidak larut diubah menjadi pektin yang larut. Akibat daya kohesi dinding sel yang satu dengan yang lainnya menurun. Penurunan daya kohesi ini selanjutnya mengakibatkan menurunnya kekerasan buah. Peningkatan nilai kekerasan disebabkan oleh penguapan air. Air sel yang menguap menjadikan sel menciut sehingga ruang antar sel menyatu dan zat pektin menjadi saling berikatan. Menurunnya kekerasan pada buah-buahan selama penyimpanan disebabkan oleh hilangnya tekanan turgor, perombakan pati menjadi glukosa dan degradasi dinding sel (Pantastico, 1993).

Pigmen Kulit Buah Sawo setelah Perlakuan Kitosan dan Suhu Rendah Warna kulit berdasarkan Munsell Color Chart for Plant Tissue

Perubahan warna kulit buah sawo selama proses pematangan diamati dengan Munsell Color Charts for Plant Tissue (Wilde dan Voigt, 1977). Tabel 8 menunjukkan bahwa semakin hari, buah semakin matang, warna kuning semakin menurun, dan warna kuning kecoklatan semakin meningkat. Pengamatan dilakukan pada kontrol saja setiap hari sampai tidak layak konsumsi. Data kualitatif berdasarkan tabel warna pada Munsell Color Charts for Plant Tissue. Pada hari pertama warna masih sama dengan hari ke 0 , baru pada hari ke 2 terjadi perubahan warna. Data warna tersebut disajikan dalam Tabel 8.

Tabel 8. Perubahan warna kulit buah sawo setelah pelapisan kitosan dan suhu selama 7 hari

\begin{tabular}{cl}
\hline Hari ke & \multicolumn{1}{c}{ Warna } \\
\hline 1 & $5 \mathrm{Y}(7 / 10$ to $7 / 12)$ \\
2 & $5 \mathrm{Y}(7 / 10$ to $7 / 12)$ \\
3 & $5 \mathrm{Y}(8 / 10$ to $8 / 12)$ \\
4 & $5 \mathrm{Y}(8 / 10$ to $8 / 12)$ \\
5 & $2,5 \mathrm{Y}(8 / 10$ to $8 / 12)$ \\
6 & $2,5 \mathrm{Y}(8 / 10$ to $8 / 12)$ \\
7 & $7,5 \mathrm{YR}(7 / 8$ to $7 / 12)$ \\
\hline
\end{tabular}

\section{Klorofil}

Perlakuan pelapisan kitosan dan suhu rendah mempengaruhi kadar klorofil a kulit buah sawo. Interaksi kedua perlakuan ini mampu mempertahankan kadar klorofil a pada kulit buah sawo tetap tinggi selama masa simpan.
Tabel 9. Klorofil kulit buah sawo (Manilkara achras (Mill.) Fosberg) setelah perlakuan dengan pelapisan kitosan dan penyimpanan suhu rendah selama tujuh hari $(\mathrm{mg} / \mathrm{l})$.

\begin{tabular}{cccc}
\hline Sitosan (\%) & 5 & 15 & 25 \\
\hline 0 & $1,22^{\mathrm{abc}}$ & $1,62^{\mathrm{abc}}$ & $0,28^{\mathrm{ab}}$ \\
2 & $0,93^{\mathrm{ab}}$ & $3,23^{\mathrm{c}}$ & $1,24^{\mathrm{d}}$ \\
3 & $2,66^{\mathrm{bc}}$ & $1,76^{\mathrm{e}}$ & $1,42^{\mathrm{abc}}$ \\
4 & $1,44^{\mathrm{abc}}$ & $0,70^{\mathrm{a}}$ & $1,73^{\mathrm{abc}}$ \\
\hline
\end{tabular}

Angka yang disertai dengan huruf yang sama pada baris/kolom menunjukkan tidak beda nyata pada taraf uji $5 \%(n=5)$.

Adapun kadar tertinggi pada perlakuan pelapisan $3 \%$ dan suhu $15{ }^{\circ} \mathrm{C}$, tetapi perlakuan $3 \%$ dan suhu $5{ }^{\circ} \mathrm{C}$ juga tinggi yaitu 2,66 . Adapun yang terendah adalah perlakuan tanpa pelapisan kitosan dan suhu $2{ }^{\circ} \mathrm{C}$ (kontrol). Data klorofil pada kulit buah sawo setelah diberi perlakuan pelapisan suhu dan kitosan ditunjukkan pada Tabel 9.

Pelapisan kitosan akan menyebabkan terjadinya penurunan respirasi. Hal ini menyebabkan terjadinya penurunan aktivitasi enzim dalam proses respirasi. Suhu dingin akan menurunkan aktivitas enzim antara lain enzim pendegradasi klorofil yaitu klorofilase, sehingga buah tetap berwarna hijau. Menurut Muchtadi dan Sugiyono (1992), beberapa penulis melaporkan adanya kegiatan klorofilase maksimum pada buah pisang dan apel pada waktu klimakterik. Oleh karena itu mereka menyimpulkan bahwa klorofilase bertanggung jawab atas penguraian klorofil. Hilangnya warna hijau pada buah karena terjadi oksidasi atau penjenuhan terhadap ikatan rangkap molekul klorofil selama proses kematangan.

\section{Karotenoid}

Hasil analisis statistik menunjukkan bahwa suhu, konsentrasi kitosan dan interaksinya mempengaruhi kadar karotenoid buah sawo. Kandungan karotenoid tertinggi diperoleh dari perlakuan suhu $25^{\circ} \mathrm{C}$ dan konsentrasi kitosan $2 \%$. Adapun data kadar karotenoid buah sawo selama perlakuan pelapisan kitosan dan penyimpanan pada berbagai variasi suhu ditunjukkan pada Tabel 10.

Perubahan warna adalah perubahan yang paling menonjol pada waktu pematangan buah. Hal ini karena terjadi sintesa pigmen tertentu, seperti karotenoid dan flavonoid di samping terjadi perombakan klorofil (Apandi, 1984). Warna buah masak disebabkan oleh sintesis karotenoid dan antosianin. Pada periode matang ditandai dengan terjadinya reduksi karoten. Untuk kebanyakan buah, tanda kematangan pertama adalah hilangnya warna hijau. Kandungan klorofil 
Tabel 10. Karotenoid kulit buah sawo (Manilkara achras (Mill.) Fosberg) setelah perlakuan dengan pelapisan kitosan dan penyimpanan suhu rendah selama tujuh hari $(\mu \mathrm{mol} / \mathrm{g})$

\begin{tabular}{cccc}
\hline Suhu $\left({ }^{\circ} \mathrm{C}\right)$ & 5 & 15 & 25 \\
\hline 0 & $0,031^{\text {de }}$ & $0,028^{\text {de }}$ & $0,001^{\mathrm{b}}$ \\
2 & $0,018^{\text {cd }}$ & $0,028^{\text {de }}$ & $0,066^{\mathrm{g}}$ \\
3 & $0,037^{\mathrm{f}}$ & $0,028^{\mathrm{h}}$ & $0,022^{\mathrm{de}}$ \\
4 & $0,021^{\text {de }}$ & $0,003^{\mathrm{bc}}$ & $0,021^{\mathrm{a}}$ \\
\hline
\end{tabular}

Angka yang disertai dengan huruf yang sama pada baris/kolom menunjukkan tidak beda nyata pada taraf uji $5 \%(\mathrm{n}=5)$.

buah yang sedang masak lambat laun berkurang, pada umumnya sejumlah zat warna hijau tetap terdapat dalam buah, terutama dalam jaringan bagian-bagian dalam buah.

Perubahan warna ini terjadi akibat adanya degradasi klorofil dan sintesa pigmen antosianin. Pada saat masak klorofil akan menghilang sehingga pigmen yang dominan adalah karotenoid dan antosianin. Karotenoid terdiri atas karoten, xanthofil dan likopen. Pembentukan pigmen pada buah dipengaruhi oleh suhu, cahaya, dan kandungan karbohidrat. Biosintesis karotenoid dipengaruhi oleh adanya gen psy-1 dan psy-2 yang akan menyandi enzim fitoen sintase. Adanya enzim tersebut akan mengawali biosintesis karotenoid (Simkin dkk., 2003).

\section{KESIMPULAN}

Semakin tinggi konsentrasi kitosan, semakin terhambat masuknya uap air dan oksigen ke dalam kulit buah, tetapi konsentrasi kitosan $4 \%$ dan suhu $5{ }^{\circ} \mathrm{C}$ menyebabkan lapisan kitosan mengelupas. Perlakuan konsentrasi pelapisan kitosan $(0 \%, 2 \%, 3 \%, 4 \%)$ dan suhu simpan $\left(5{ }^{\circ} \mathrm{C}, 15^{\circ} \mathrm{C}, 25^{\circ} \mathrm{C}\right)$ serta interaksinya mengakibatkan semakin tinggi konsentrasi kitosan, kekerasan buah sawo semakin meningkat, juga kadar klorofil kulit buah. Semakin matang buah, semakin meningkat kadar karotenoidnya, demikian juga kadar $\mathrm{CO}_{2}$. Sebaliknya, kadar oksigen semakin menurun seiring dengan pemasakan buah. Perlakuan optimum untuk mempertahankan masa simpan buah sawo adalah perlakuan pelapisan kitosan $3 \%$ dan suhu simpan $5{ }^{\circ} \mathrm{C}$.

\section{DAFTAR PUSTAKA}

Abdou, E.S., Nagy, K.S.A. dan Elsabee, M.Z. (2008). Extraction and characterization of chitin and chitosan from local sources. Bioresources Technology 99(5):1359-1367.
Apandi, M. (1984). Teknologi Buah dan Sayur. IPB Press, Bandung.

ASTM. (2004). Standard Test Method for Oxygen Gas Transmission Rate Through Plastic Film and Sheeting Using a Coulometric Sensor1. ASTM International. United States.

Beckett, S.T. (1995). Physico-Chemical Aspect of Food Processing. $1^{\text {st }}$ edition. Blackie Academic and Professional, London.

Bourtoom, T. (2008). Edible films and coatings: characteristics and properties. International Food Research Journal Technology 15(3): 237-248.

Chailoo, M.J. danAsghari, M.R. (2011).Hot water and chitosan treatment for the control of postharvest decay in sweet cherry (Prunus avium L.) cv. Napoleon (Napolyon). Journal of Stored Products and Postharvest Research 2(7): 135-138.

Dirk, I. (2007). Cell Cycle Control Plant Development. Blackwell Publishing Ltd. New York.

Donhowe, L.G. dan Fennema, O.R. (1993). The effects of plasticizers on crystallinity, permeability, and mechanical properties of methylcellulose films. Journal Food Process Pres 17: 247-257.

Donhowe, L.G. dan Fennema, O.R. (1994). Edible film and coating characteristics, formation, definition and testing methods. Dalam: Krochta, J.M., Baldwin, E.A. dan Nisperos-Cariedo, M.O. (eds). Edible Film and Coating Improve Food Quality.Technomic Publisher Co. Inc, Landcaster.

Dopico, B., Lowe, A.L., Wilson, I.D., Merodio, C. dan Grierson, D. (1993). Cloning dan characterization of avocado fruit mRNAs dan their expression during ripening dan low-temperature storage. Plant Molecular Biology 21: 437-449.

Ghaouth, R., Ponnampalam, F., Castaigne dan Arul, J. (1992). Chitosan coating to extend the storage life of tomatoes. Hortscience 27(9): 1016-1018.

Heldt, H.W. (2005). Plant Biochemistry. Elsevier Academic Press. USA.

Jaleel, C.A. dan Azooz, M.M. (2009). Exogenous calcium alters pigment composition, $\gamma$-glutamyl kinase and proline oxidase activities in salt-stressed Withania somnifera. Plant Omics Journal 2(2): 85-90.

Kurniawan, D., Trisnowati, S., Muhartini, S. (2013). Pengaruh macam dan kadar kitosanterhadap pematangan dan mutu buah sawo (Manilkara zapota (L.) van Royen). Vegetalika 2 (2): 21-30. 
Muchtadi, T.R. dan Sugiyono (1992). Ilmu Pengetahuan Bahan Pangan. PAU Pangan dan Gizi Institut Pertanian Bogor, Bogor.

Pantastico, E.R.B. (1993). Fisiologi Pasca Panen, Penanganan, dan Pemanfaatan Buah-Buahan dan Sayuran Tropika dan Subtropika. Diterjemahkan oleh: Kamariyani. UGM Press, Yogyakarta.

Paramita, O. (2010). Pengaruh memar terhadap perubahan pola respirasi, produksi etilen, dan jaringan buah mangga (Mangifera indica L.) var gedong gincu pada berbagai suhu penyimpanan. Jurnal Kompetensi Teknik 2(1): 29-37.

Richardson, A.D, Duigan, S.P. dan Berlyn, G.P. (2002). An evaluation of non invasive methods to estimate foliar chlorophyll content. New Phytologist 153: 185-194.

Rohman, T., Baroroh, U., Utami, L. dan Mahmud (2009). Pengaruh konsentrasi kitosan terhadap karakter membran. Sains dan Terapan Kimia 2(1): 14-24.

Santoso, B.B. (2011). Fisiologi dan Biokimia pada Komoditi Panenan Hortikultura. Fakultas Pertanian, Universitas Mataram, Mataram.
Shehata, S.A., Fawzy, Z.F. dan El-Ramady, H.R. (2012). Response of cucumber plants to foliar application of chitosan and yeast under greenhouse conditions. Australian Journal of Basic and Applied Sciences 6(4): 63-71.

Simkin, A.J., Laboure, A.M., Kuntz, M. dan Sandmann, G. (2003). Comparison of carotenoid content, gene expression, and enzyme levels in tomato (Lycopersicon esculentum) leaves. Zeitschrift fur Naturforschung $\mathbf{5 8}$ 371-380.

Wahab, S.M.A. dan Rashid, I.A.S. (2012). Safe postharvest treatment for controlling Penicillium molds and its impact maintaining navel orange fruits quality. American-Eurasian Journal Agriculture and Environmental Science 12(7): 973-982.

Winarno, F.G. (2002). Fisiologi Lepas Panen Produk Hortikultura. M-BRIO Press, Bogor.

Wilde, S.A. dan Voigt, G.K. (1977). Munsell Color Charts for Plant Tissues. Munsell Color Gretagmacbeth, New York.

Zeman, S. dan Kubik, L. (2012). Evaluation of oxygen permeability of polyethylene films. Abbrev Technology Science 15(2): 331-345. 